\title{
Phytoplankton Species Composition and Physico-chemical Characteristics of Ismailia Canal, Egypt
}

\author{
Ahmed Y. M. Yusuf, Amal I. Saleh and Hesham M. Abd El Fatah* \\ Botany Department, Faculty of Science, Ain Shams University, Cairo, 11566, Egypt
}

\begin{abstract}
Ismailia Canal is one of the main artificial branches of River Nile in Egypt, it is the most important one as a source of water supply for several governorates in the east of Nile Delta. In this study, phytoplankton composition and some physico- chemical parameters have been studied in twelve points along the main route of Ismailia canal between Cairo and Ismailia governorates to follow up changes in the water quality of the canal. Samples have been collected monthly in the period from February 2015 to January 2016. A total of 143 phytoplankton taxa related to 55 genera were identified related to six algal divisions namely; Chlorophyta (69 taxa), Bacillariophyta (51 taxa), Cyanophyta (18 taxa), Euglenophyta and Dinophyta (each represented by 2 taxa) and finally Xanthophyta represented by one taxon. Quantitatively, Bacillariophyta was the most dominant division with algal density represented more than $86 \%$ of average total phytoplankton count. The highest phytoplankton density was recorded in winter, while the minimum was recorded in summer. Water of Ismailia Canal was found to be slightly alkaline. Concentrations of nitrogen, phosphorus and silicate were found to be markedly affected by the water level of the canal along the year as well as the pollution runoff from ambient pollution sources. Phytoplankton composition of the canal also seems to be affected by pollutants especially at the far eastern part of the canal that located in Ismailia city. On the long run increasing of industrial and agricultural run-off may affect the water quality of the canal, so continuous studies must be carried out to follow up the changes in water of the canal.
\end{abstract}

Key Words: Egypt, Freshwater algae, Ismailia canal, Phytoplankton, River Nile, Water quality.

\section{Introduction}

Ismailia Canal is one of the main artificial branches of the River Nile, it is the most important one as a source of water supply for several governorates in the east of Nile Delta (Badr El-Din et al., 2015), as it transports about 5 million $\mathrm{m}^{3}$ of water for drinking and domestic uses per day (Abdo, 2013), which meet the 
needs of more than 12 million inhabitants which represent about $15 \%$ of Egypt's total population distributed in four governorates ( Madkour et al., 2015).

The canal receives a lot of waste water from the industrial activities such as petroleum, petrogas, iron and steel and detergent factories as well as water treatment plants and power station, which caused dramatic changes in its water quality (Abdo and El-Nasharty, 2010). It also receives drainage from agricultural run-off e.g. El-Mahsama pumping station which pumping agricultural waste water from El-Mahsama drain into Ismailia canal (Stahl and Ramadan, 2008). Microbial contamination with viruses and bacteria in addition to inorganic and organic pollution were all found their way to the canal water (Geriesh et al., 1999).

As one of the most important branches of Nile and one of the most endangered, Ismailia canal has received attention of many researchers with various points of interests. Water quality of Ismailia Canal and distribution of heavy metals in it were the most interesting points for many authors, (El-Sayed, 2008; Geriesh et al., 2008; Stahl and Ramadan, 2008; Ibrahim et al., 2009; Abdo, 2010; Abdo and El-Nasharty, 2010; Youssef et al., 2010; Abd El-hady and Hussian, 2012; Abdo et al., 2012; Nassif, 2012; Abdo, 2013; Goher et al., 2014; Khalifa, 2014; Korium and Toufeek, 2015 and Abdel-Shafy et al., 2018). However, few studies have dealt with the relation between water quality of the canal and its algal community (Abd El-hady and Hussian, 2012; Abd ElKarim, 2014 and Badr El-Din et al., 2015). In this study we aimed to assess the current water quality status of Ismailia canal by following up its physico-chemical characteristics and phytoplanktonic variations, to reveal the relationship between environmental factors and temporal and spatial distribution of phytoplankton.

\section{Materials and Methods}

\section{a. Study area}

Ismailia canal was constructed in the years of 1858 to1862 to supply drinking water to the villages in the Suez Canal zones and to the workers during digging of the Suez Canal Navigation Route (Geriesh et al., 2008). The canal is about $128 \mathrm{~km}$ long, 1-3 $\mathrm{m}$ depth and its width ranging from $30-70 \mathrm{~m}$ (Stahl and Ramadan, 2008). The water level of the canal is about $10 \mathrm{~m}$ above sea level and 
the average of its water velocity is $0.28 \mathrm{~m} / \mathrm{s}$ (Ibrahim et al., 2009). It extends eastward from the River Nile at Shubra El-Balad, north of Cairo, to Ismailia city on the Suez Canal. At Ismailia it bifurcates into two arms: one to the north to supply Port Said governorate and the second to the south to feed Suez governorate, then a short part without current directly connects the canal to the Suez Canal at Timsah lake.

The study area was the main route of Ismailia Canal which extends eastward for about $128 \mathrm{~km}$ from the River Nile at Shubra El-Balad, north of Cairo $\left(30^{\circ} 6^{\prime} 19^{\prime \prime} \mathrm{N}, 31^{\circ} 14 ' 34 " \mathrm{E}\right)$ to Ismailia city on the Suez Canal $\left(30^{\circ} 35^{\prime} 24^{\prime \prime} \mathrm{N}\right.$, $\left.32^{\circ} 17^{\prime} 55^{\prime \prime} \mathrm{E}\right)$. Twelve sampling stations were selected to cover as much as possible the different localities of the canal and to be near the inlet of different drinking water treatment plants along the canal. The twelve stations of sampling are distributed in four governorates: Cairo, Kalyoubya, Sharqya, and Ismailia with three localities for each governorate (Fig. (1)).

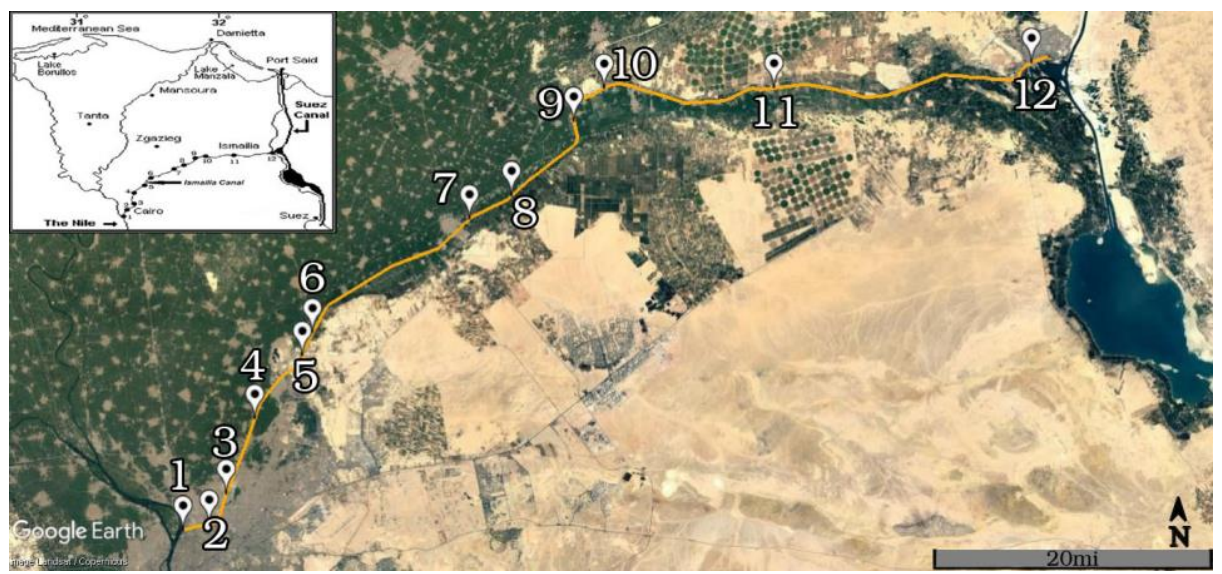

Fig. (1): Sampling localities along the main route of Ismailia canal

\section{b. Collection of samples}

A total of 144 phytoplanktonic samples were collected monthly from 12 different stations along the main route of Ismailia canal. Samples were collected monthly during the period from February 2015 to January 2016. From each 
sampling locality, fifteen liters of canal subsurface water were collected and filtered by $15 \mu \mathrm{m}$ mesh plankton net into a total fixed volume of $100 \mathrm{ml}$. Samples were preserved in $4 \%$ formalin for identification of different algal groups. In addition, one liter of canal subsurface water was collected in polyethylene plastic bottles for further chemical analysis in laboratory.

\section{c. Preparation and identification of algal samples}

Diatom samples were cleaned from organic matter by hot $\mathrm{H}_{2} \mathrm{O}_{2}$ method and mounted in permanent slides according to Taylor et al. (2007). Examination, identification and counting were carried out using oil immersion lens (100 X) in case of diatoms and $40 \mathrm{X}$ lens in case of other algal taxa of trinocular microscope (Microstar AO). Identification of algal taxa was carried out according to Desikachary, (1959); Prescott, (1961); Patrick and Reimer, (1966 and 1975); Jensen, (1985); Krammer and Lang-Bertalot, (1986, 1988); Round et al. (1990) and Steidinger and Tangen (1996).

\section{d. Physico-chemical Analysis}

Water temperature and $\mathrm{pH}$ were determined at the time of sampling using portable $\mathrm{pH}$ meter with thermometer (AZ Model:8686). Turbidity was determined using turbidity meter (EZTECH TU-2016). Dissolved oxygen concentration in water was determined using dissolved oxygen meter (JENWAY model 970). Alkalinity, salinity, ammonium, nitrate, nitrite, phosphate and silicate concentrations were detected according to methods described in APHA (2012).

\section{e. Statistical Analysis}

Canonical correspondence analysis (CCA) was used to explore the distribution of the most common phytoplankton taxa along major environmental gradients. CCA was carried out with Canoco for Windows version 4.5 for phytoplankton taxa whose average frequency $\geq 1000$ individuals/L. CCA triplot of species - Environmental variables - and months of collection were drawn with Cano Draw for Windows. 


\section{Results and Discussion}

Water quality of the canal varied monthly at different parameters. Mean values of physical and chemical properties of Ismailia canal water during the study period were shown in Table (1). It was observed that air temperature was slightly higher than the corresponding values of water temperature along the studied stations in the canal. Water temperature readings exhibited monthly fluctuations where the minimum average value was recorded in February $\left(15.9^{\circ} \mathrm{C}\right)$ and the maximum average was recorded in July $\left(30.6^{\circ} \mathrm{C}\right)$.

Relative increase in temperature in some parts of the canal (stations 6 and 12) was observed, which may be due to that these parts of the canal is exposed to thermal pollution by the discharge of water that is used in cooling machinery in the industrial suburb along canal bank (Stahl and Ramadan, 2008).

The turbidity records were found to be related to chlorophyll $a$ records of Ismailia canal as both variables show a simultaneous fluctuation during the study time. Both turbidity and chlorophyll $a$ concentrations reached their minimum average in July (7.14 NTU and $29.7 \mathrm{mg} / \mathrm{L}$, respectively), while both reached their maximum in September (17.45 NTU and $105.01 \mathrm{mg} / \mathrm{L}$, respectively). These results indicate that the turbidity of the canal water may be caused mainly by the phytoplankton biomass.

Spatial distribution of both turbidity and chlorophyll average levels showed a significant decrease at the eastern part of the canal, and this result matched with the fact that this part of the canal has a considerably low phytoplankton density during all seasons as compared with other parts of the canal.

The present results revealed that $\mathrm{pH}$ of Ismailia canal tends to be slightly alkaline. The average $\mathrm{pH}$ records of the canal show a seasonal fluctuation, with maximum average $\mathrm{pH}$ recorded in March (8.7), while the minimum average was in July (7.5). The slightly alkaline nature of Ismailia canal water was reported by many other authors (Stahl and Ramadan, 2008; Abdo and El-Nasharty, 2010; Abd El-hady and Hussian, 2012; Khalil et al., 2012; Abdo, 2013; Elhaddad, 2014; Khalifa, 2014; Korium and Toufeek, 2015 and Abdel-Shafy et al., 2018). This tendency to the alkaline side may be due to the increased photosynthetic activity of phytoplankton, or to the chemical nature of water (Hansen, 2002). 


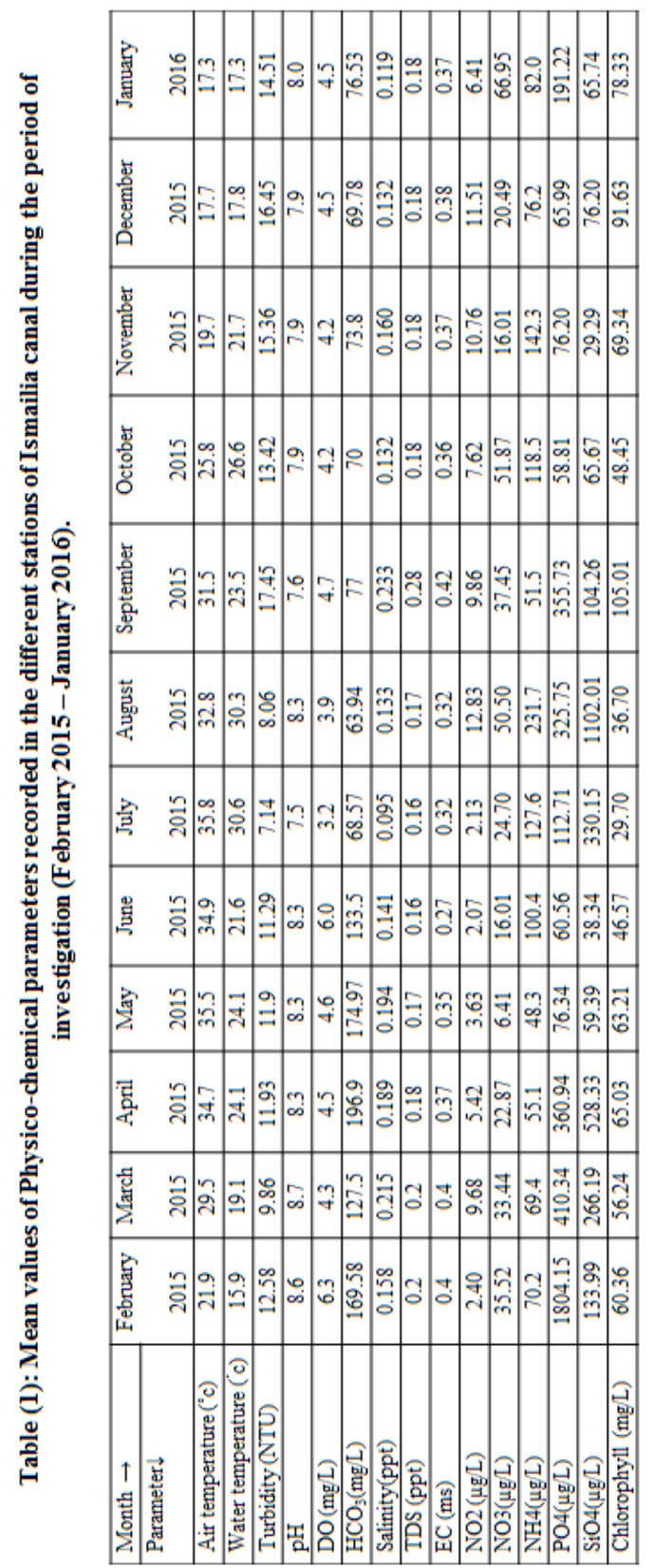


The alkalinity of Ismailia canal in this study was expressed by bicarbonate ion concentrations, since carbonate levels in the canal is too low and sometimes it's totally absent. These results were agree with many authors (Ali, 2008; Abdo and El-Nasharty, 2010 and Abdo, 2013). The present data reveals that bicarbonate concentration in Ismailia canal is relatively high, this may be ascribed to the occurrence of high amount of organic matter accessible to bacterial decomposition and fermentation, where the $\mathrm{HCO}_{3}{ }^{-}$is the final product of this process (Abdo, 2013). Bicarbonate shows a seasonally considerable variation but with no significant changes between sampling sites along the canal. The maximum average bicarbonate concentration was recorded in May $(174.97 \mathrm{mg} / \mathrm{L})$ while minimum average concentration was recorded in August $(63.94 \mathrm{mg} / \mathrm{L})$. These findings agree with Khalil et al. (2012) who found that water alkalinity of Ismailia canal changes only seasonally not spatially, with maximum alkalinity in spring and minimum in summer.

As revealed from the present results, the water of Ismailia canal is oxygenated during all seasons which agree with Abd El-hady and Hussian (2012). The average values of dissolved oxygen content of Ismailia canal water ranged between $6.3 \mathrm{mg} / \mathrm{L}$ in February and decreased to $3.2 \mathrm{mg} / \mathrm{L}$ during July. Many studies stated that the DO content in winter is higher than any season (Toufeek and Korium, 2009; Abd El-hady and Hussian, 2012), and the lowest DO content in River Nile and Ismailia canal is detected in summer in other studies (Khalil et al., 2012; Abdel-Satar et al., 2017).

The seasonal variation of average salinity of Ismailia canal shows minimum value in July by $0.095 \%$, while reaching its maximum in September by average value of $0.233 \%$. Many authors stated that chloride concentration reaches highest levels in cold seasons and drop to lowest levels in hot seasons (AbdelSatar, 2005; Abdo and El-Nasharty, 2010 and Abdo, 2013). Similar variation patterns were observed for TDS and EC values, as both reached their maximum average values in September by TDS $=0.28 \mathrm{ppt}$, and $\mathrm{EC}=0.42 \mathrm{~ms}$ and this agree with reports confirmed that maximum EC values of Ismailia canal detected in autumn ( El-Sayed, 2008; Khalil et al., 2012; Nassif, 2012 and Khalifa, 2014). The minimal averages of both TDS and EC was recorded in summer (TDS=0.16 ppt in both June and July) which agree with Abdel-Satar et al. (2017) and ( $E C=0.27 \mathrm{~ms}$ in June) which agree with Abd El-hady and Hussian (2012). This pattern of fluctuation can be explained by change in water flow of River Nile and 
its branches. The decrease of flow level of Nile in winter tends to concentrate the ions, resulting in high records of EC, TDS, and salinity (Islam et al., 2015). In contrast, the values dropped in the summer season due to high dilution effect (Abdel-Satar et al., 2017).

Nutrient concentrations (nitrogen and phosphorus) showed significant temporal and spatial changes along Ismailia canal during the period of study. Ammonia-N accounted for the major proportion of total soluble inorganic nitrogen (Abdo, 2013). Ammonium ion average concentration $\left(\mathrm{NH}_{4}\right)$ showed a great increase in summer than in winter and reached their minimum by $48.3 \mu \mathrm{g} / \mathrm{L}$ in May. The average ammonium concentration shows a spatial fluctuation with higher levels at the beginning and the end of the canal. The increase in ammonium in the beginning of the canal may confirm the assumption of Stahl and Ramadan (2008) that the highly urban and industrial activity in Cairo governorate affects the water quality at the beginning of the canal, while at the end of the canal it may be because this part of the canal located very near to Timsah lake and so it has little or no flow current which led to little dilution effect.

In contrast to ammonium, Nitrate $\left(\mathrm{NO}_{3}\right)$ and Nitrite $\left(\mathrm{NO}_{2}\right)$ average values show a slight variation between different sampling sites along the canal, while both show increase in their average values during winter and autumn and decrease during summer (Table 1). This agree with some reports that mentioned the decrease of nitrate and nitrite in summer and increase in winter and this pattern may be attributed to the uptake of nitrate by natural phytoplankton as well as the effect of denitrifying bacteria (Abdo, 2010; Khalil et al., 2012). It's also noticeable that the average concentrations of nitrate were always greater than that of nitrite, and this may be attributed to the fast conversion of nitrite to nitrate by nitrifying bacteria (Shama et al., 2011).

Phosphorus is one of the most frequent limiting elements affecting the succession of phytoplankton (Xu et al., 2010 and Shah et al 2019). The concentration of orthophosphate along Ismailia canal varies locally with interrupted monthly variation, with maximum average concentration recorded in February $(1804.15 \mu \mathrm{g} / \mathrm{L})$ and minimum recorded in October $(58.81 \mu \mathrm{g} / \mathrm{L})$. This results completely agree with Abdo and El-Nasharty (2010) and Abdo (2013). 
Focusing on local variations, there is a recorded exceptional superelevation of orthophosphate concentrations in February at the middle part of the canal. Dredging activity has been detected very close to this part of the canal at the same time of sampling. Dredging causes sediments to mix with surface water and therefore causing dissolution of trace metals, decomposed died organisms, and other constituent of sediment in surface water (Carvalho et al., 2002). High measures of turbidity and silicate at this part of the canal in the same months confirm that this odd change in orthophosphate content is related to the mixing with sediments during dredging.

The lower water level and low water flow during February may cause two effects: first: it facilitates the death and decaying of many microorganisms in water column (Nesbeda, 2004; Abdo, 2013), which leading to liberation of different ions especially ortho and total-P, this is probably why orthophosphate levels still high but fainting gradually in the next two months, and second: it prevents spread of phosphate contamination from the middle part of the canal to other parts. Relative increase in phosphate level has been observed in location near by Abu Zaa'bal fertilizers company (Station 6) during several months. Many authors denoted its effect on the canal water quality (Stahl and Ramadan, 2008; Abdo and El-Nasharty, 2010; Khalil et al., 2012; Nassif, 2012 and Abdo, 2013).

Dissolved silica plays an important role in diatom growth. Silicate concentration reached the maximum average value in August by $1102.01 \mu \mathrm{g} / \mathrm{L}$, while this value decreased gradually until reach the minimum average silicate concentration in November by $29.29 \mu \mathrm{g} / \mathrm{L}$, this depletion in silicate may be explained as diatoms consumption of dissolved silica in its growth forming blooming in next winter months (Abdo, 2013).

A total of 143 phytoplankton taxa related to 55 genera were identified from Ismilia canal. These taxa related to six algal divisions namely; Chlorophyta (represented by 19 genera and 69 taxa), Bacillariophyta (represented by 21 genera and 51 taxa), Cyanophyta (represented by 10 genera and18 taxa), Euglenophyta and Dinophyta (each represented by 2 genera and 2 taxa) and finally Xanthophyta represented by one genus and one taxon. 
The maximum average phytoplankton density was recorded in December by 2174390 individuals/L, and the minimum average number of taxa was recorded in January by only 56 taxa. This was due to the domination of the two diatoms Synedra ulna var. danica and Cyclotella ocellata in massively great counts during winter.

Concerning phytoplankton counting in Ismailia canal, the minimum algal biomass was observed in July by 519511 individuals/L with the largest average number of taxa was recorded in April by 103 taxa.

In average, chlorophytes reached their maximum density in summer by 112481 individuals/L recorded in August. Diatoms, specially the most dominant taxa Synedra ulna var. danica and Cyclotella ocellata, reached their maximum counts in winter by average count of 2066974 individuals/L in December, and their minimum counts in summer by average count of 323256 individuals $/ \mathrm{L}$ in July (Fig. 2). These results agree with El-manawy and Amin, (2004) who studied winter algal bloom in Suez freshwater canal and reported that temperature is inversely proportional to algal biomass, and also agree with Abd El-hady and Hussian (2012) who mentioned that diatoms in Ismailia canal flourish in winter and reached their minimum productivity in summer, while chlorophytes density increase in warm seasons and drop with temperature decrease. In contrast, studies of phytoplankton in drainage waters and some marine and brackish lakes reported that maximum algal biomass is reached in summer, while minimum was recorded in winter (Salah El Din, 2005; Abd El-Fatah, 2010 and Badr El-Din et al., 2015). This contradiction may be explained as temperature is not the only factor that control phytoplankton growth and its effect may interfere with other water quality parameters for different types of aquatic systems. In addition, low temperature and low water level can cause blooming of diatoms (Wetzel, 2001).

Regarding the total number of taxa recorded in the different months during this study, it was found that Chlorophyta occupied the $1^{\text {st }}$ rank in all months except in February and July where the number of taxa related to Bacillariophyta exceeded the number of taxa recorded in all other groups (Fig. 3). Chlorophyta represented by $48.3 \%$ of total number of identified taxa, followed by Bacillariophyta (35.7\%), then Cyanophyta (12.6\%) and 3.5\% for other divisions. 


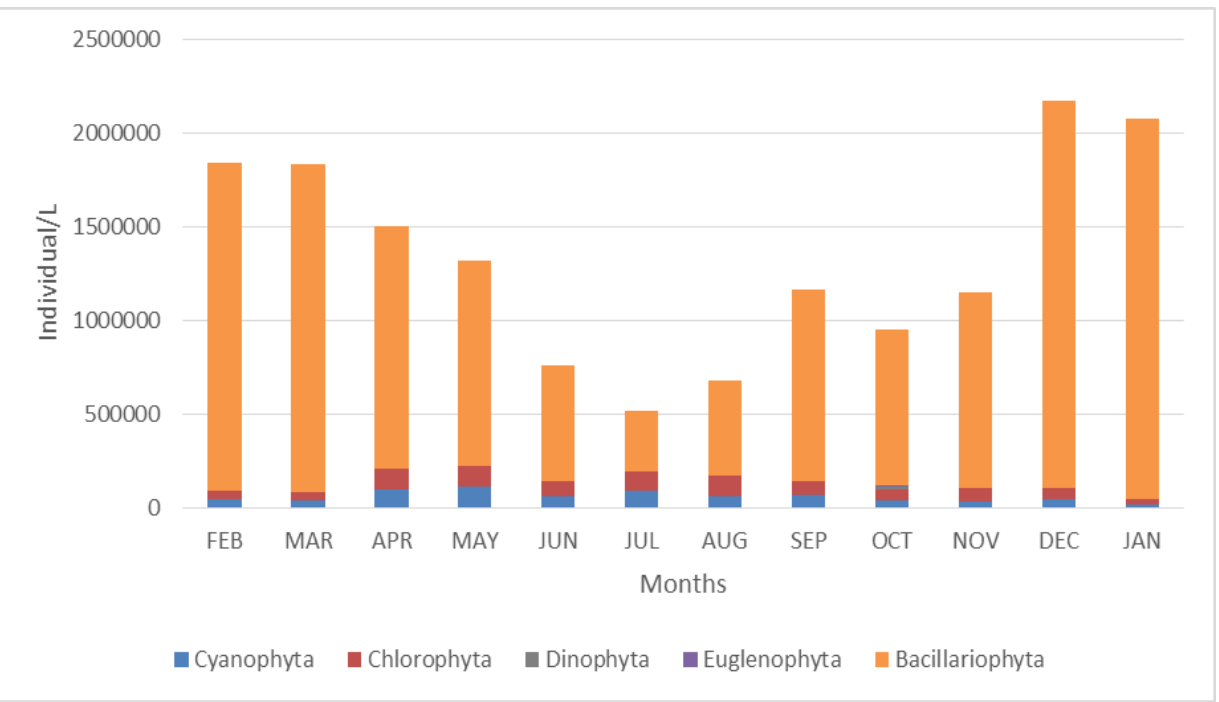

Fig. (2): Mean phytoplankton density (no. of individuals/L) of different algal divisions recorded in the different stations of Ismailia canal during the period of investigation.

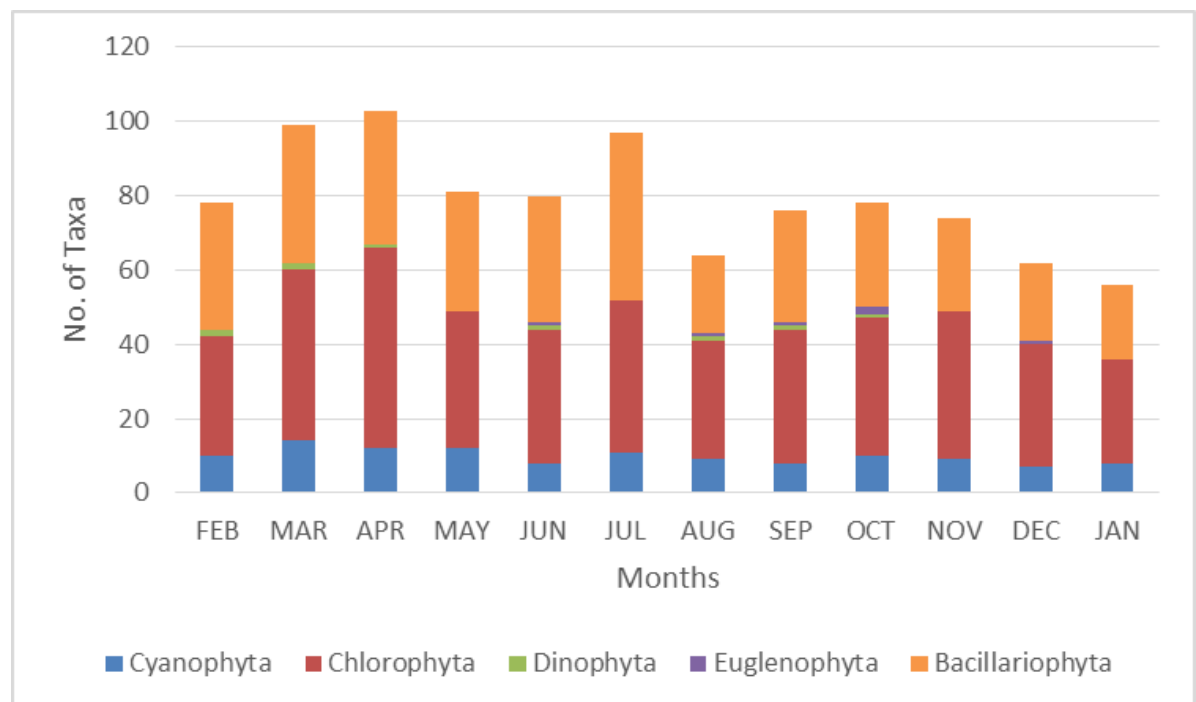

Fig. (3): Mean number of taxa of different algal divisions recorded in the different stations of Ismailia canal during the period of investigation. 
Algae are one of the most powerful bioindicators of the changes in water quality and trophic state of any water resource. Diatoms have been used frequently as bioindicators because they have some advantages over other groups of organisms (Stoermer and Smol, 2004). Synedra ulna var. danica, Cyclotella ocellata, Melosira granulata, M. granulata var. angustissima and Synedra ulna var. aequalis were the most productive diatom taxa recorded in the present study. These taxa have been classified by Van Dam et al. (1994) as $\beta$-mesosaprobic and eutrophic forms except Cyclotella ocellata which appeared to be sensitive to highly contaminated conditions and prefer mesotrophic environments (CastroRoa and Pinilla-Agudelo, 2014).

Therefore, according to trophic status of the canal and the dominance of these diatoms taxa in the water of the canal it was regarded that water quality of canal was relatively good along different stations and this is in agree with the findings of Abd El-Karim (2014).

Although algal flora of Ismailia canal shows no remarkable variation in phytoplankton composition or count between different sampling sites, there was a prominent exception at the eastern part of the canal which differs from all other parts of the canal in many criteria. It's located at the end of the canal near its fusion with Suez Canal, where water current is almost absent (Stahl and Ramadan, 2008), and the canal width and depth at this region is minimal. These criteria make this site very sensitive to changes in water quality. As can be revealed from the results of nutrient levels at this part in different months, it's not exposed to a nearby pollution source and characterized originally by low nutrient content and low algal density in most of the study time. But, when the water flow rate of the canal increased, this part becomes as a sink of pollutants accumulated from other upstream parts of the canal which lead to increase in its nutrient content during this period (O'Farrell et al., 2003).

These remarkable changes in water quality of this sensitive point of the canal have led to change in phytoplankton composition that started slightly at June, fade in July, and continue from August until reached its climax at October with complete change in phytoplankton floral composition, showing a bloom of the two motile algae Euglena gracilis and Peridinium cinctum. October is lie 
within the drought period when death and decaying of most microorganisms in water column takes place, causing organic pollution and anaerobic condition, in addition to receiving accumulation of nutrients from agricultural run-off in previous months.

Dinoflagellates often dominate the phytoplankton community in shallow water bodies that are thermally stratified with vertically separated resources (Regel et al., 2004), while Euglenoids are characterized by being able to tolerate anaerobic conditions and being recorded in ponds receiving heavy organic loads (Amengual-Morro et al., 2012). This may explain why the phytoplankton community was dominated by blooming of the dinoflagellate Peridinium cinctum, beside Euglena gracilis at the end of the canal.

According to Canonical correspondence analysis (CCA) triplot shown in Fig. 4, it can be revealed that there is a typical inverse relationship between dissolved oxygen content and water temperature that the solubility of oxygen decreases with the increase in temperature and this was in accordance with Abowei (2010). Ammonia- $\mathrm{N}$ is also inversely correlated to dissolved oxygen which may be due to the conversion of ammonia to nitrate and nitrite through oxidation and vice versa through reduction (Abd El-Fatah, 2010). In contrast, it was found that chlorophyll $a$ concentration and dissolved oxygen content were directly correlated. This could explain the relatively high concentrations of dissolved oxygen recorded in winter and late spring that may be attributed to the increased photosynthetic activity of phytoplankton populations (Abd El-hady and Hussian, 2012; Khalifa, 2014). The lowest dissolved oxygen content was recorded in July and this may be due to phytoplankton population and chlorophyll concentration reached their minimum value at the same month, or it also may be attributed to the elevation of water temperature and the increase in oxidative processes of organic matter which lead to oxygen depletion (Abdel-Satar and Elewa, 2001; Abdel-Satar, 2005; Elewa et al., 2007; Khalil et al., 2012 and Abd El-hady, 2014). 


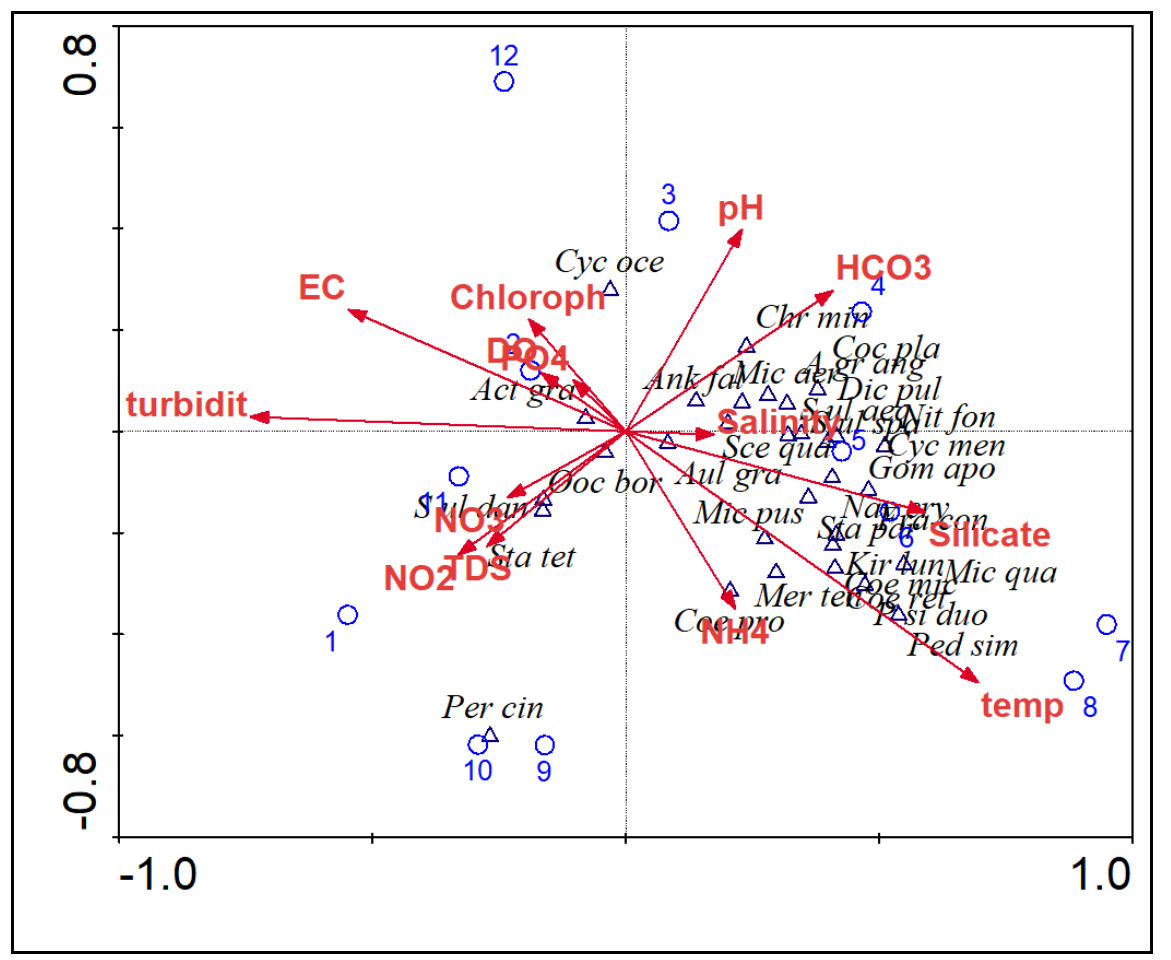

Fig. (4): Triplot of Canonical Correspondence Analysis showing the relationships between the twelve months of sampling (circles), algal flora (triangles), and physicochemical parameters (arrows) of Ismailia canal.

$\mathrm{pH}$ and alkalinity are two related factors that affect each others and affect phytoplankton populations. Changes of $\mathrm{pH}$ were found to affect the interspeciation of inorganic carbon (as dissolved $\mathrm{CO}_{2}, \mathrm{HCO}_{3}{ }^{-}$, or $\mathrm{CO}_{3}{ }^{2-}$ ), the more the $\mathrm{pH}$ value the less the dissolved $\mathrm{CO}_{2}$ and the more the $\mathrm{HCO}_{3}{ }^{-}$concentration (Fathi and Kobbia, 2000; Hansen, 2002). In addition, phytoplanktons can uptake $\mathrm{HCO}_{3}{ }^{-}$by active transport to use it as a source of carbon (Huertas et al., 2000; Cassar et al., 2004). This may explain why $\mathrm{HCO}_{3}{ }^{-}$concentration is shown to be effective factor for many phytoplankton taxa in the CCA triplot. 
Based on CCA triplot (Fig. 4), it was found that most chlorophytes, cyanophytes and some diatom taxa were greatly affected by temperature. In general, the water of Ismailia canal was characterized in winter by major algal densities with minor diversity, while in summer and spring maximum number of taxa was recorded with less algal density. It could be also concluded that temperature also affects both turbidity and chlorophyll $a$ concentration. This agree with Touliabah and Taylor (2004) who mentioned that discharge of hot water in lake Timsah caused decreases in chlorophyll content and phytoplankton abundance. Increasing in turbidity of Ismailia canal in winter was also mentioned by Abd El-hady and Hussian (2012) and they attributed that to the decrease of water level during drought period. Primmer (2009) reported that chlorophyll $a$ concentration not always give an accurate indication about phytoplankton count, and there is no apparent relationship between chlorophyll $a$ concentration and the taxonomic composition of phytoplankton community.

\section{Conclusion}

In conclusion, the canal water has the ability to renew itself, but the increasing industrial and agricultural run-off may alter the water quality of the canal on the long run. It also can be concluded from the above results that decreasing water levels can cause accumulation of pollutants and lower the ability of the canal to renew, especially in its far part at Ismailia, causing blooms of Euglenoids and Dinoflagellates. Overall, it was concluded that water quality of canal was relatrively good along different stations. It's recommended that continuous studies must be carried out to follow up the changes in water quality of the canal.

\section{References}

Abd El-Fatah, H.M. (2010). Algal studies on Qarun and Wadi El-Rayan lakes, Egypt. Ph. D.Thesis,Faculty of Science - Ain shams University. 445 p.

Abd El-hady, H.H. (2014). Alternations in biochemical structures of phytoplankton in Aswan Reservoir and River Nile , Egypt. J. Biodivers. Environ. Sci. 4: 68-80. 
Abd El-hady, H.H. and Hussian, A.M. (2012). Regional and Seasonal Variation of Phytoplankton Assemblages and its Biochemical. J. Appl. Sci. Res. 8: 3433-3447.

Abd El-Karim, M.S. (2014). Epipelic algal distribution in Ismailia Canal and the possible use of diatoms as bioindicators and a biomonitoring tool. Egypt. J. Aquat. Res. 40: 385-393.

Abdel-Satar, A.M. (2005). Water Quality Assessment of River Nile From Idfo To Cairo. Eyptian J. Aquat. Res. 31: 200-223.

Abdel-Satar, A.M. and Elewa, A.A. (2001). Water quality and environmental assessments of the River Nile at Rossetta Branch, in: The Second International Conference and Exhibition for Life and Environment. 136164.

Abdel-Satar, A.M., Ali, M.H. and Goher, M.E. (2017). Indices of water quality and metal pollution of Nile River, Egypt. Egypt. J. Aquat. Res. 43: 21-29.

Abdel-Shafy, H. I., Salem, M. A., Mansour, M. S., El-Khateeb, M. A. and Abdel-Shafy, S. H. (2018). Physico-Chemical Evaluation of Drinking Water Treatment Plant and Sand Filter Backwashing Water for Possible Recycling: A Case Study. Egyptian Journal of Chemistry, 61(6): 10391047.

Abdo, M.H. (2010). Environmental and water quality evaluation of Damietta branch, River Nile, Egypt. African J. Biol. Sci., 6: 143-158.

Abdo, M.H. (2013). Impact of Drought Period on Water Quality and Trace Metals Distributions in Water and Sediment of Ismailia Canal, River Nile, Egypt. Life Sci. J. 10(4): 485-492.

Abdo, M.H. and El-Nasharty, S.M. (2010). Physico-Chemical Evaluations And Trace Metals Distribution in Water-Surficial Sediment of Ismailia Canal, Egypt. Nat. Sci. 8: 198-206.

Abdo, M.H., Goher, M.E. and Sayed, M.F. (2012). Environmental evaluation of Ismailia Canal water and sediment, Egypt. J. Egypt. Acad. Soc. Environ. Dev., 13: 61-78.

Abowei, J.F.N. (2010). Salinity, dissolved oxygen, $\mathrm{pH}$ and surface water temperature conditions in Nkoro River, Niger Delta, Nigeria. Adv. J. Food Sci. Technol., 2: 36-40. 
Ali, M.H.H. (2008). Assessment of some water quality characteristics and determination of some heavy metals in Lake Manzala, Egypt. Egypt. J. Aquat. Biol. Fish. 12: 133-153.

Amengual-Morro, C., Moyà Niell, G. and Martínez-Taberner, A. (2012). Phytoplankton as bioindicator for waste stabilization ponds. J. Environ. Manage. 95: 6-11.

APHA (2012). Standard Methods for examination of water and wastewater. 22nd ed. Washington: American Public Health Association, 1360 pp.

Badr El-Din, S. M., Hamed, A.H.S., Ibrahim, A.N., Shatta, A.-K.M. and AboSedera, S.A. (2015) . Phytoplankton in irrigation and draining water canals of east Nile Delta of Egypt. G.J.B.A.H.S. 4: 56-60.

Carvalho, L., Bennion, H., Dawson, H., Furse, M., Gunn, I., Hughes, R., Johnston, A., Maitland, P., May, L. and Monteith, D. (2002). Nutrient conditions for different levels of ecological status and biological quality in surface waters (Phase I). R\&D Technical Report P2-260/4 (Final Report to the Environment Agency.) 289 p.

Cassar, N., Laws, E.A., Bidigare, R.R. and Popp, B.N. (2004). Bicarbonate uptake by Southern Ocean phytoplankton. Global Biogeochem. Cycles 18: 1-10.

Castro-Roa, D. and Pinilla-Agudelo, G. (2014). Periphytic diatom index for assessing the ecological quality of the Colombian Andean urban wetlands of Bogotá. Limnetica, 33 (2): 297-312.

Desikachary, T.V. (1959). Cyanophyta. Indian Council of Agricultural Research. New Delhi. 686 pp.

Elewa, A.A., Saad, E.A., Shehata, M.B. and Ghallab, M.H. (2007). Studies on the effects on the water quality of Lake Manzala, Egypt. Egypt. J. Aquat. Biol. Fish. 11: 65-78.

Elhaddad, E. (2014). Effects of pollution on hydro-chemical and water quality assessment of the Ismailia Canal water, Egypt. Int. J. pure Appl. Biosci. 2 (5): 124-131.

El-manawy and I.M., Amin, A.S. (2004). A wintertime Blue-Green algal bloom in the Suez freshwater Canal , Egypt. Egypt. J. Nat. Toxins 1: 135-152.

El-Sayed, S.A. (2008). Microbiological studies on Ismailia Canal, River Nile, Egypt. M. Sc. Thesis, Fac. Sci, Al-Azhar Univ., p. 198. 
Fathi, A.A. and Kobbia, I.A. (2000). Hydrobiological investigation of AbouMedian lake, El-Minia, Egypt. Bullten Fac. Sci. Assiut Univ. 29: 77-91.

Geriesh, M.H., El-Shamy, I.Z. and Farouk, H. (1999). Source of Pollution of the Sweet Suez Canal Water, Suez Canal Province, Egypt, in: 4th International Conference of Geochemistry. Alexandria, Egypt, pp. 353368.

Geriesh, M.H., Balke, K.D. and El-Rayes, A.E. (2008). Problems of drinking water treatment along Ismailia Canal Province, Egypt. J. Zhejiang Univ. Sci. B., 9: 232-242.

Goher, M.E., Hassan, A.M., Abdel-Moniem, I.A., Fahmy, A.H. and ElSayed, S.M. (2014). Evaluation of surface water quality and heavy metal indices of Ismailia Canal, Nile River, Egypt. Egypt. J. Aquat. Res. 40: 225-233.

Hansen, P.J. (2002). Effect of high pH on the growth and survival of marine phytoplankton: Implications for species succession. Aquat. Microb. Ecol. 28: 279-288.

Huertas, I.E., Colman, B., Espie, G.S. and Lubian, L.M. (2000). Active transport of $\mathrm{CO} 2$ by three species of marine microalgae. J. Phycol. 36: 314-320.

Ibrahim, H.S., Ibrahim, M.A. and Samhan, F.A. (2009). Distribution and bacterial bioavailability of selected metals in sediments of Ismailia Canal, Egypt. J. Hazard. Mater. 168: 1012-1016.

Islam, M.S., Uddin, M.K., Tareq, S.M., Shammi, M., Kamal, A.K.I., Sugano, T., Kurasaki, M., Saito, T., Tanaka, S. and Kuramitz, H. (2015). Alteration of water pollution level with the seasonal changes in mean daily discharge in three main rivers around Dhaka City, Bangladesh. Environments. 2: 280-294.

Jensen, N. G. (1985). The Pennate Diatoms. A translation of Hustedt's "Die Kieselalgen, 2. Teil." Koeltz Scientific Books, Koenigstein, 918 pp.

Khalifa, N. (2014). Population dynamics of Rotifera in Ismailia Canal , Egypt. J. Biodivers. Environ. Sci. 4: 58-67.

Khalil, M.T., Amer, A.S., Sayed, M.M. and Nassif, M.G. (2012). Impact of pollution on macroinvertebrates biodiversity in Ismailia Canal, Egypt. Egypt. J. Aquat. Biol. Fish. 16: 69-89. 
Korium, M.A., and Toufeek, M.E.F. (2015). Environmental Evaluation of Major and Minor Metals in Ismailia Canal Sediment. Int. J. Environ.4(4): 219-227.

Krammer, K. and Lange-Bertalot, H. (1986). Bacillariophyceae. 1. Teil:Naviculaceae. In: Süsswasserflora von Mitteleuropa. Band 2/1. H. Ettl; J. Gerloff; H. Heynig and D. Mollenhauer (eds.).Gustav Fisher Verlag, Stuttgart, 876 pp.

Krammer, K. and Lange-Bertalot, H. (1988). Bacillariophyceae. 2. Teil: Bacillariaceae, Epithemiaceaeand Surirellaceae. In: Süsswasserflora von Mitteleuropa. Band 2/2. H. Ettl; J. Gerloff; H. Heynig and D. Mollenhauer (eds.). Gustav Fisher Verlag, Stuttgart, 821 pp.

Madkour, F. F., Shalaby S. M., Sultan Y. Y., Dessouki A. A. and Mohammed A. A. (2015). Detection of microcystin-LR in water supply at one of the Egyptian water treatment plants with potential use of a novel absorbent material for its removal. International Journal of Environmental Science and Engineering (IJESE). 6: 75 - 84.

Nassif, M.G. (2012). Ecological studies on aquatic invertebrates of Ismailia Canal, Egypt. Faculty of Science, Ain Shams University.

Nesbeda, R.H. (2004). Sedimentological and geochemical characterization of east pond, Belgrade Lakes Watershed, Central Maine. Faculty of the Geology, Waterville, Maine 114pp.

O'Farrell, I., Sinistro, R., Izaguirre, I. and Unrein, F. (2003). Do steady state assemblages occur in shallow lentic environments from wetlands? In: Phytoplankton and Equilibrium Concept: The Ecology of Steady-State Assemblages. Springer, pp. 197-209.

Patrick, R. and Reimer, C. W. (1966). The diatoms of the United States (Exclucive of Alaska and Hawaii). Vol. 1: Fragilariaceae, Eunotiaceae, Achnanthaceae, and Naviculaceae. Monogrs. Acad. Sci. Philad. 13: 688 pp.

Patrick, R. and Reimer, C. W. (1975). The diatoms of the United States (Exclucive of Alaska and Hawaii). Vol.2, Part 1: Entomoneidaceae, Cymbellaceae, Gomphonemaceae, and Epithemiaceae. Monogrs. Acad. Sci. Philad. 13: 213 pp.

Prescott, G. W. (1961). Algae of the western great lakes area. Wm. C. Brown Publishers, Dubuque, Iowa, USA. 977 pp. 
Primmer, I. (2009). Chlorophyll a and phytoplankton survey, Otsego Lake.

Regel, R.H., Brookes, J.D. and Ganf, G.G. (2004). Vertical migration, entrainment and photosynthesis of the freshwater dinoflagellate Peridinium cinctum in a shallow urban lake. J. Plankton Res. 26: 143157.

Round, F. E., Crawford, R. M. and Mann, D. G. (1990). The diatoms: biology and morphology of the genera. Cambridge University Press, Cambridge, 747 pp.

Salah El Din, R.A. (2005). Changes in Physico-Chemical Characters and Its Impact on Phytoplankton Structure of Lake Manzala. Egypt. J. Phycol. 6: 111-126.

Shah, Z., Shah, S. Z., Shuaib, M., Khan, K. N., Khan, T. and Hussain, F. (2019). Effect of water quality on algal diversity in various sites of district Charsadda, Khyber Pakhtunkhwa (KPK)-Pakistan. Pure and Applied Biology $(P A B), \mathbf{8}(\mathbf{1})$ : 169-186.

Shama, S.A., Goher, M.E., Abdo, M.H., Kaial, S.M. and Ahmed, A.A. (2011). Physico-chemical characteristics and heavy metal contets in water of Wadi El-Rayan Lakes, western desert, Egypt. Egypt. J. Aquat. Biol. Fish. 15: 225-240.

Stahl, R. and Ramadan, A.B. (2008). Environmental Studies on Water Quality of the Ismailia Canal, Egypt. Scientific Report, Forschungszentrum Karlsruhe in der Helmholtz-Gemeinschaft Wissenschaftliche Berichte FZKA 7427, p. 58.

Steidinger, K. A. and Tangen, K. (1996). Dinoflagellates. In: C. R. Tomas (ed.), Identifying Marine diatoms and Dinoflagellates, Academic Press, New York: 387-598.

Stoermer, E. and Smol, J. (2004). The diatoms, applications for the environmental and earth sciences. Cambridge University Press, Cambridge, United Kingdom.

Touliabah, H.E. and Taylor, W.D. (2004). The phytoplankton of Great Bitter Lake, Egypt, including the impacts of nutrient-laden and heated effluents. African J. Aquat. Sci. 29: 259-264.

Toufeek, M.A.F. and Korium, M.A. (2009). Physicochemical Characteristics of Water Quality in Lake Nasser Water. Glob. J. Environ. Res. 3: 141-148. 
Taylor, J.C., Harding W.R. and Archibald C.G.M. (2007). A Methods Manual for the Collection, Preparation and Analysis of Diatom Samples. Version 1.0. WRC Report No. TT281/07. Water Research Commission, Pretoria. ISBN: 1-77005-483-9.

Van Dam, H.; Mertens, D. and Sinkeldam, J. (1994). A coded checklist and ecological indicator values of freshwater diatoms from the Netherlands. Neth. J. Aquat. Ecol., 28(1): 117-133.

Wetzel, R.G. (2001). Limnology: Lake and River Ecosystems. gulf professional publishing, pp 985.

Xu, H., Paerl, H.W., Qin, B.Q., Zhu, G.W. and Gao, G. (2010). Nitrogen and phosphorus inputs control phytoplankton growth in eutrophic Lake Taihu, China. Limnol. Oceanogr. 55: 420-432.

Youssef, M., El-Taweel, G.E., El-Naggar, A.Y., El-Hawary, S.E., El-Meleigy, M.A. and Ahmed, S.A. (2010). Hydrocarbon Degrading Bacteria as Indicator of Petroleum Pollution in Ismailia Canal, Egypt. World Appl. Sci. J. 8: 1226-1233. 


\title{
التركيب النوعى للهائمات النباتية والخواص الفيزيائية و الكيميائية لترعة الإسماعيلية، مصر والخو
}

\author{
أحمد يوسف محمد يوسف، أمل ابراهيم صالح، هثام محمد عبد القتاح \\ قسم النبات ـ كلبة العلوم - جامعة عبن شمس
}

تعد ترعة الإسماعيلية من أهم روافد نهر النيل الاصطناعية فى مصروهى المصدر

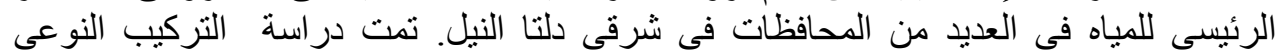

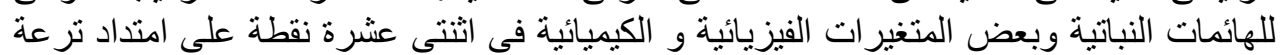

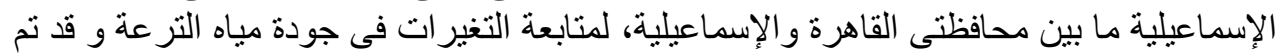
تجميع العينات دوريا كل شهر فى المدة بين فبر اير 2015 و يناير 2016.

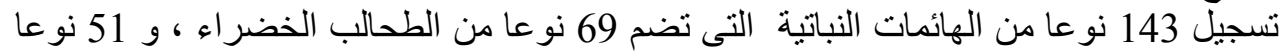

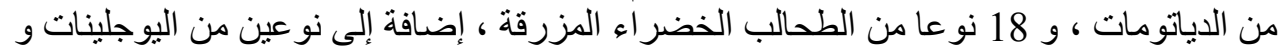

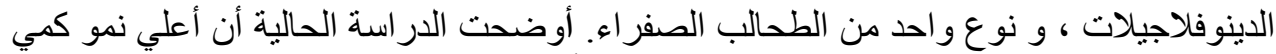

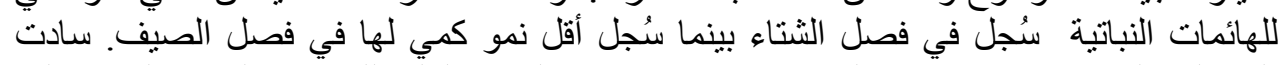
الطحالب العصوية كميا حيث مثلت 86 \% من متوسط الكثافة الكلّية للهائمات النباتية التى سجلت فئي فى هذه الدر اسة.

أظهرت النتائج أن مياه تر عة الإسماعيلية لها أس هيدروجينى قلوى ضعيف، كما أوضحت

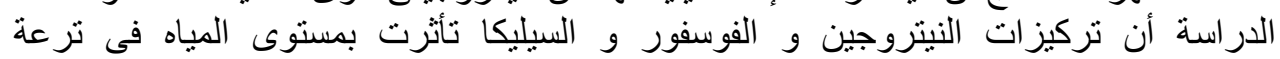

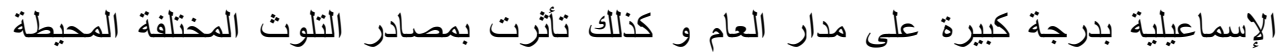

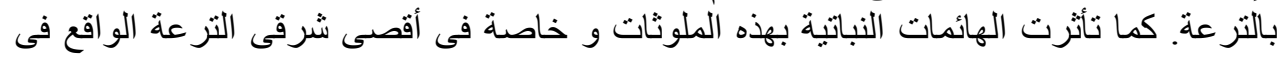

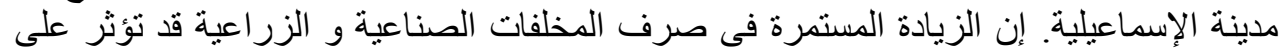
المدى الطويل على جودة مياه ترعة الإسماعيلية، ولهذا يجب عمل درة دراسات مستمرة لمتابعة التغير ات فى جودة مياه التر عة التردي 